\title{
Seasonal changes in basking shark vertical space use in the north-east Atlantic
}

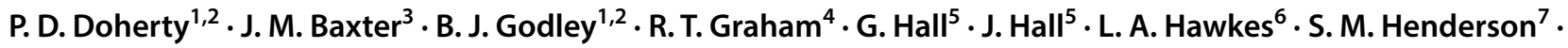 \\ L. Johnson ${ }^{8} \cdot$ C. Speedie ${ }^{8} \cdot$ M. J. Witt ${ }^{2,6}$
}

Received: 16 May 2019 / Accepted: 14 August 2019 / Published online: 18 September 2019

(c) The Author(s) 2019

\begin{abstract}
Mobile marine species can exhibit vast movements both horizontally and vertically. Spatial analysis of vertical movements may help improve an understanding of the processes that influence space use. Previously, vertical space use of basking sharks (Cetorhinus maximus) in the north-east Atlantic described movements largely within waters of the continental shelf during summer and autumn months, with few records of detailed vertical behaviour during winter. We use archival satellite telemetry data from 32 basking sharks ( 12 females, 6 males, and 14 of unknown sex measuring 4-5 $\mathrm{m}(n=6), 5-6 \mathrm{~m}(n=10), 6-7 \mathrm{~m}$ $(n=7), 7-8 \mathrm{~m}(n=8)$, and 8-9 $\mathrm{m}(n=1)$ estimated total length) tracked over 4 years (2012-2015). The satellite tags provided depth and temperature data for a cumulative 4489 days (mean 140 \pm 97 days per shark, range 10-292 days) to describe vertical space use and thermal range of basking sharks in the north-east Atlantic. Basking sharks exhibit seasonality in vertical space use, revealing repeated 'yo-yo' movement behaviour with periods of occupancy at depths greater than $1000 \mathrm{~m}$ in late winter/early spring. Describing seasonal vertical space use in marine megavertebrates can increase knowledge of movements throughout their environment including physiological and morphological constraints to movement, nutrient transfer, and overlap with anthropogenic threats to inform future conservation strategies.
\end{abstract}

\section{Introduction}

Describing seasonal and migratory movements in many large marine vertebrates is challenging, largely due to the complexities of tracking individuals in water for sufficient

Responsible Editor: J. K. Carlson.

Reviewed by undisclosed experts.

Electronic supplementary material The online version of this article (https://doi.org/10.1007/s00227-019-3565-6) contains supplementary material, which is available to authorized users.

P. D. Doherty

p.doherty@exeter.ac.uk

1 Centre for Ecology and Conservation, University of Exeter, Penryn Campus, Cornwall TR10 9FE, UK

2 Environment and Sustainability Institute, University of Exeter, Penryn Campus, Cornwall TR10 9FE, UK

3 Scottish Natural Heritage, Silvan House, 231 Corstorphine Road, Edinburgh EH12 7AT, UK

4 MarAlliance, PO Box 283, San Pedro, Ambergris Caye, Belize time to obtain meaningful insight into migratory behaviour (Hammerschlag et al. 2011). Advances in satellite tracking technologies and attachment techniques now allow for observations of movements and space use over extended timescales (Hazen et al. 2012a; Hussey et al. 2015). These advance our ability to describe life-history events (Block et al. 2011; Hussey et al. 2015) and reveal an extraordinary array of behaviours from ocean basin migrations (Bonfil et al. 2005), to remarkable individual dive profiles into depths greater than $2500 \mathrm{~m}$ (Schorr et al. 2014).

Knowledge of vertical movements can provide insight into how animals use their environment (Musyl et al.

5 Manx Basking Shark Watch, Glen Chass Farmhouse, Glen Chass, Port St Mary IM9 5PJ, Isle of Man

6 Hatherly Laboratories, College of Life and Environmental Sciences, University of Exeter, Exeter EX4 4PS, UK

7 Scottish Natural Heritage, Great Glen House, Inverness, Scotland IV3 8NW, UK

8 Wave Action, 3 Beacon Cottages, Falmouth TR 11 2LZ, UK 
2011). Some parameters such as light, pressure, and temperature vary with depth, which can partition species ranges due to morphological and physiological constraints (Hussey et al. 2015). Animal movements between habitats may affect trophic dynamics such as nutrient transport between depth zones, which can represent a significant contribution to ecosystem nutrient cycling (Frid et al. 2009; Schmitz et al. 2010; Matich et al. 2011; Thorrold et al. 2014). For heavily exploited species, and species of conservation concern, coupling knowledge on vertical with horizontal movement behaviour is essential to fully understand the potential for overlap with specific fishing gear types and activity. With sharks in particular, reducing susceptibility to fisheries as bycatch is a major priority (Barker and Schluessel 2005; Hetherington et al. 2015; Oliver et al. 2015; Dulvy et al. 2017).

Historically, basking sharks were heavily exploited by directed fisheries in the north-east Atlantic, resulting in marked declines in local populations (Kunzlik 1988). This led to the IUCN listing the north-east Atlantic stocks as Endangered, with global populations assessed as Vulnerable (Fowler 2005). Incidental catch can still occur-with sharks caught annually in the bottom gill-net fishery in the Celtic Sea (Berrow 1994), and in trawl and set net fisheries in New Zealand (Francis and Duffy 2002). Basking sharks are protected under national (such as the Wildlife and Countryside Act (1981)) and international treaties, including being listed in Appendix II of the Convention on International Trade in Endangered Species of Wild Fauna and Flora (CITES), and Appendices I and II in the Convention of Migratory Species (CMS) requiring international trade to be monitored.

Previous studies in the north-east Atlantic on vertical space use of basking sharks have shown that the majority of time is spent occupying shallow surface waters during the summer (Sims et al. 2003; Stéphan et al. 2011) moving into deeper, mesopelagic waters as winter approaches (Sims et al. 2003; Gore et al. 2008; Stéphan et al. 2011; Doherty et al. 2017a). Many of these studies, however, have been limited in tracking duration to see fine-scale vertical space use throughout winter. These patterns have also been described in the north-west Atlantic (Skomal et al. 2009; Braun et al. 2018). Sims et al. (2003) suggested that vertical movements were consistent with those associated with foraging, with animals likely feeding year round on zooplankton. These behaviours, however, differed with habitat type: when in deep stratified waters of the continental shelf-edge, basking sharks exhibited normal diel vertical migration (DVM; dusk ascent-dawn descent), but when in shallow, inner-shelf waters basking sharks conducted reverse diel vertical migration (rDVM; dusk descent-dawn ascent; Sims et al. 2005; Stéphan et al. 2011; Queiroz et al. 2017). Basking sharks were also shown to switch behaviours to a tidal rhythm when encountering boundaries between thermally stratified and mixed waters (Shepard et al. 2006).

Analysing fine-scale depth data can help identify patterns in vertical space use and gain insight into the underlying factors that influence habitat selection and behaviour (Vaudo et al. 2014; Afonso and Hazin 2015; Queiroz et al. 2017), particularly for species of conservation concern, such as basking sharks. Using data from archival satellite tags deployed on basking sharks, our aims were to (1) quantify basking shark depth and temperature distributions and vertical space use patterns, (2) investigate whether basking shark vertical space use varies throughout the year, and (3) investigate potential factors that might influence vertical behaviour.

\section{Methods}

\section{Tag attachment and specification}

Satellite tags were attached to basking sharks from a boat, using a titanium M-style dart (Wildlife Computers, Redmond, California, USA) inserted at the base of the first dorsal fin with a modified pole spear. Tags were attached via a tether consisting of heat-shrink covered stainless steel flexible cable, a swivel and monofilament line attached to the tag. Sharks were sexed when possible using a pole-mounted camera, and total body length estimated against the length of the survey vessel $(10 \mathrm{~m})$.

Thirty-two archival satellite tags (Mini Pop-up Archival (MiniPAT, $n=10$ ), and Pop-up Archival Transmitting with Fastloc ${ }^{\text {TM }}$ GPS tags (PAT-F, $n=9$; SPLASH-F, $n=13$; Wildlife Computers, Washington, USA) were attached to basking sharks off the west coast of Scotland during July and August of 2012-2014. These tags were programmed to summarise depth data at $4 \mathrm{~h}$ intervals across twelve depth ranges of; 0-1 m, 1-5 m, 5-10 m, 10-25 m, 25-50 m, 50-75 m, 75-100 m, 100-250 m, 250-500 m, 500-750 m, $750-1000 \mathrm{~m}$, and $>1000 \mathrm{~m}$, along with 12 temperature ranges of $0{ }^{\circ} \mathrm{C}, 0-4{ }^{\circ} \mathrm{C}, 4-6{ }^{\circ} \mathrm{C}, 6-8{ }^{\circ} \mathrm{C}, 8-10{ }^{\circ} \mathrm{C}, 10-12{ }^{\circ} \mathrm{C}$, $12-14{ }^{\circ} \mathrm{C}, 14-16{ }^{\circ} \mathrm{C}, 16-18{ }^{\circ} \mathrm{C}, 18-20{ }^{\circ} \mathrm{C}, 20-22{ }^{\circ} \mathrm{C}$, and $>22^{\circ} \mathrm{C}$. Maximum reported daily depths of sharks were used to estimate vertical position within the water column during wide-ranging movements.

\section{Location data processing}

To observe movements into winter months, light geolocation data were obtained from archival tags with attachment durations into at least the January following tag attachment ( $>165$ days; $n=12$; Doherty et al. 2017a). Hidden Markov Models (HMM; Neilson et al. 2014) were applied using light level, temperature, and depth data recorded by the tag to estimate the most likely track of individuals from high 
quality light measurements (Thygesen et al. 2009; by Collecte Localisation Satellites (CLS-Argos; www.argos-syste m.org)). For a detailed description of specific parameters of HMMs applied, see (Biais et al. 2017; Doherty et al. 2017a). In brief, to reconstruct the most probable track of basking sharks, HMMs were used to estimate the daily probability density (or Utilisation Distribution; UD) of the location of tracked animals (Thygesen et al. 2009). The HMM used a two-step process: first, at each sampling time a position prediction was made and, second, the predicted probability density was combined with latitude, longitude, SST, and depth recorded onboard the tag to produce the posterior distribution of the individual (Biais et al. 2017). These data were constrained by bathymetry (etopo2; https ://www.ngdc.noaa.gov/mgg/global/etopo 2.html), SST (GHRSST-OSTIA; https://www.ghrsst.org/), and known deployment and pop-off locations with daily location estimates were taken as the geographic mean of the grid locations weighted by their probability (Thygesen et al. 2009).

To examine variability in depth occupancy with respect to geographic location, polygon sampling grids [each cell was $50 \mathrm{~km}$ from grid cell centroid to perimeter; (cell area $8660 \mathrm{~km}^{2}$ ) encompassing mean error across all light-based geolocation estimates $(98 \mathrm{~km})$ ] were created, bounded by the maximum limits of observed movement. These grids were spatially intersected with light geolocated tracking locations. The mean daily minimum and mean daily maximum depth within each grid cell were calculated for each shark and then averaged (mean) across all individuals calculated. Times of night and day were determined by applying sunrise and sunset times for mean latitude and longitude of occupancy within each month obtained using the suncalc package (Agafonkin and Thieurmel 2018) in R (R Core Team 2018).

A General Additive Model (GAM) was performed to investigate the relationship between the maximum daily depth occupied by basking sharks, latitude the depth was occupied at (fitting a cyclic cubic regression spline for each month), or month in which the depth occupancy occurred. Months included in the model were restricted to months outside of peak times of high occupancy of surface waters, retaining September to April. The response variable of daily maximum depth was $\log _{\mathrm{e}}$ transformed to fulfil assumptions of normality of data with individual shark identification number and year of deployment fitted as separate random effects. Models were fitted using the $m g c v$ package (Wood 2017) and ranked by Akaike's Information Criteria (AIC) using subset selection of the maximal model using the MuMIn package (Barton 2018). All terms within the maximal model were examined fixing month in the model to minimise bias of estimates from centred smooth terms. Top ranked models were defined as models $\Delta \mathrm{AIC} \leq 6$ units of the best supported model (Harrison et al. 2018).
Sea surface temperature (SST) values were obtained from monthly averaged MODIS L3 nighttime remotely sensed rasters $\left({ }^{\circ} \mathrm{C} ; 4 \mathrm{~km}\right.$ resolution, http://podaac.jpl.nasa.gov) prepared using Marine Geospatial Ecological Tools v0.8a64 (Roberts et al. 2010). Temporally specific locations were used to extract SST values and averaged for each month across years for the study period.

Data analyses were performed in R (R Core Team 2018) and all spatial analyses and maps created using Geospatial Modelling Environment (GME v 0.7.2.1; Beyer 2012) and ESRI ArcMap 10.1.

\section{Results}

\section{General vertical space use}

Thirty-two archival satellite tags (Table S1. PAT-F; $n=9$, MiniPAT; $n=10$, SPLASH-F; $n=13$ ) were attached to basking sharks in $2012(n=9), 2013(n=14)$, and $2014(n=9)$. Satellite tags were attached to 12 females, 6 males and 14 individuals of unknown sex, measuring 4-5 $\mathrm{m}(n=6)$, 5-6 $\mathrm{m}(n=10), 6-7 \mathrm{~m}(n=7), 7-8 \mathrm{~m}(n=8)$, and 8-9 $\mathrm{m}$ $(n=1)$ estimated total length. These tags transmitted depth and temperature data over a cumulative 4489 days (mean $140 \pm 97$, range 10-292 days; Table S1). Sharks spent on average more time in shallower waters in the peak of summer [July; most occupied depth class $=0-1 \mathrm{~m}$ ( $21 \%$ of time), August; $25-50 \mathrm{~m}(25 \%)$ ], particularly during the daytime [July; most occupied depth class in the day $=0-1 \mathrm{~m}$ ( $25 \%$ of time), compared to $10-25 \mathrm{~m}$ at night (23\% of time), August; $0-1 \mathrm{~m}$ in the day (27\%), compared to $25-50 \mathrm{~m}$ at night $(28 \%)]$. In the peak of the winter, sharks were generally in waters away from the surface [December; most occupied depth class $=50-75 \mathrm{~m}$ (28\% of time), January; 75-100 m (19\%)], but were shallower during the night-time (December; most occupied depth class in the day $=50-75 \mathrm{~m}$ ( $28 \%$ of time), compared to $25-50 \mathrm{~m}$ at night (28\% of time), January; $100-250 \mathrm{~m}$ in the day (18\%), compared to 50-75 $\mathrm{m}$ at night (24\%); Tables S2 and S3; Figs. 1 and S1).

Sharks exhibited evidence of spatially explicit depth occupancy in the north-east Atlantic. During the peak summer months (July-August), sharks occupied shallow waters off the west coast of Scotland and north Northern Ireland. These sharks moved further south along the west coast of Ireland and into the Irish and Celtic Seas during autumn (September-October) exhibiting maximum depth occupancy greater than $100 \mathrm{~m}$. During the early winter (November-December), sharks began to move into waters off the continental shelf, west of the Bay of Biscay remaining in epipelagic waters. Late winter and early spring (January-March) showed the emergence of use of waters greater than $750 \mathrm{~m}$, most often occurring west of the Bay of Biscay towards the Iberian 


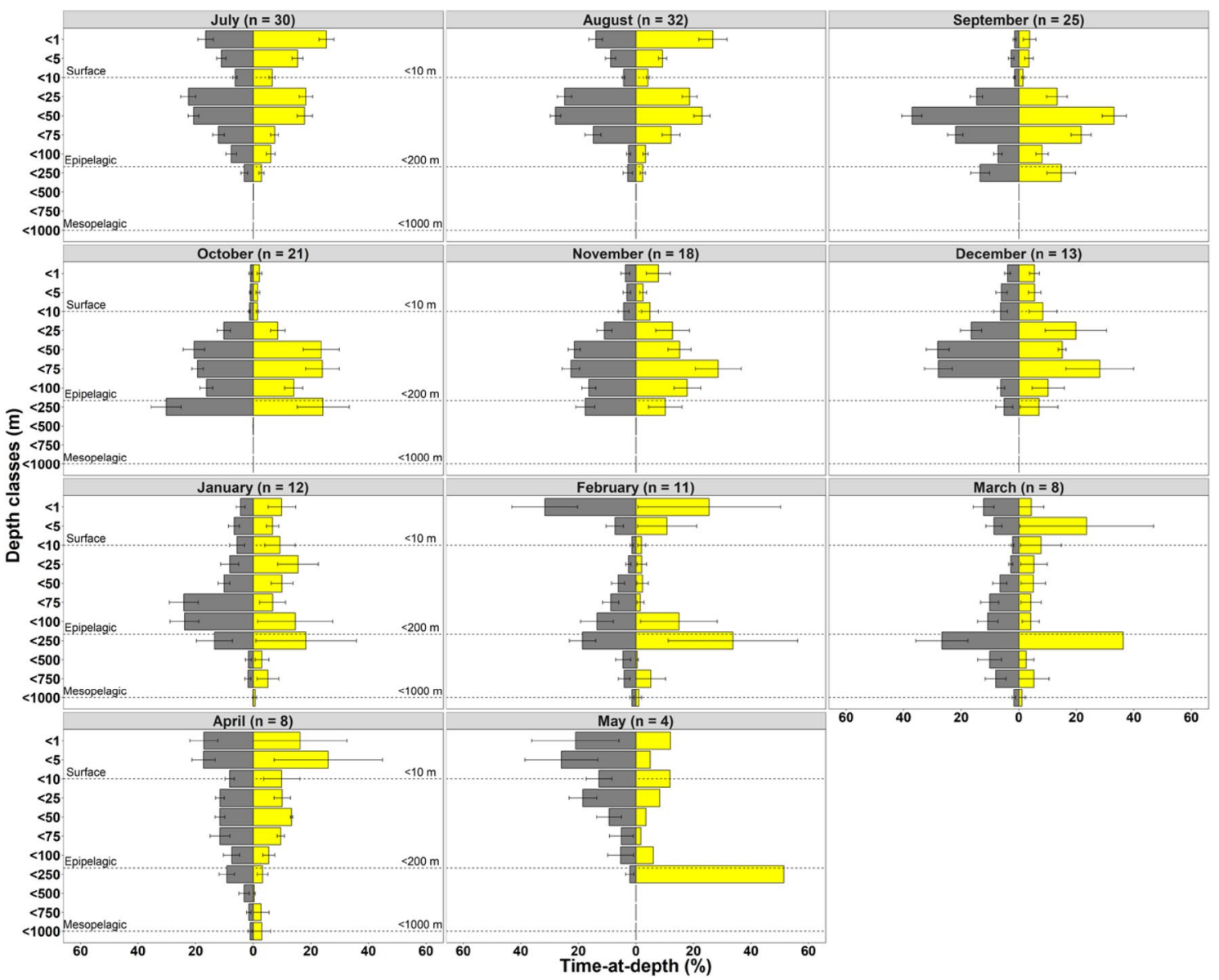

Fig. 1 Monthly time-at-depth occupancy of basking sharks by time of day. Mean time-at-depth for basking sharks $(n=32)$ for each month of tag attachment. Bars represent mean percentage of time (summarised in 4-h intervals) occupying eleven depth ranges \pm standard error (se)

Peninsula. During spring (April-May), sharks exhibited a contraction of spatial extent, within waters closer to the coasts of Ireland and the UK, showing increased occurrence of maximum depths in waters shallower than $250 \mathrm{~m}$ (Fig. 2). Occupancy of deeper waters appeared not to be governed by bathymetry as maximum depths were not at the seafloor and often remained within the epipelagic zone when in higher latitudes (Fig. 2).

\section{Individual variation in vertical space use}

Analysis of vertical space use of basking sharks with extended tracking durations ( $>165$ days; $n=12$ ) revealed occupancy of deep waters ( $>500 \mathrm{~m}$ ) during late winter-early spring (Fig. 3). Seven of the twelve sharks also used waters greater than $1000 \mathrm{~m}$, with two sharks reaching depths of 1500 m (Fig. 3; Table S1).

Five of the 12 archival tags with attachment durations greater than 165 days were physically recovered, allowing for day (yellow bars) and night (grey bars). Number of sharks contributing to each monthly plot shown. Dotted lines denote labelled ocean zones

for high-resolution time-series (depth and temperature data recorded at 10-15 s intervals) profiles to be obtained (Table S1). Data indicated a seasonal shift in vertical space use from summer to autumn/winter where sharks moved into deeper waters, spent less time associated with surface waters, and experienced smaller fluctuations in water temperature (Fig. 4). These time-series data also revealed a conspicuous switch in vertical movements from a relatively uniform use of 50-250 m depths during the winter, to deep, rapid and repeated 'bounce' or 'yo-yo' dive behaviour from depth to surface waters in late winter-early spring. These movements were often carried out whilst making more directed movements off the continental shelf (Fig. 4).

Maximum daily depths occupied by basking sharks were shown to be influenced by the latitude in which the depth occupancy occurred and varied throughout the year. There was a trend of occupancy of deeper water occurring at lower latitudes (south of $50^{\circ} \mathrm{N}$ ) with January to April 
Fig. 2 Grid density enumeration of monthly minimum and maximum depths for satellite tracked basking sharks. Mean daily minimum and mean daily maximum depth of basking sharks on a hexagonal grid (cell edge size: $50 \mathrm{~km}$; cell area: $8660 \mathrm{~km}^{2}$ ). Locations derived from modelled light geolocation positions from archival tags for basking sharks $(n=12)$. Country international two letter codes shown in regional map (UK United Kingdom, IE Ireland, FR France, ES Spain, $P T$ Portugal, and MA Morocco). Broken black line denotes $200 \mathrm{~m}$ depth contour. Maps projected in Europe Albers Equal Area Conic coordinates system. Number of sharks contributing to each monthly plot shown

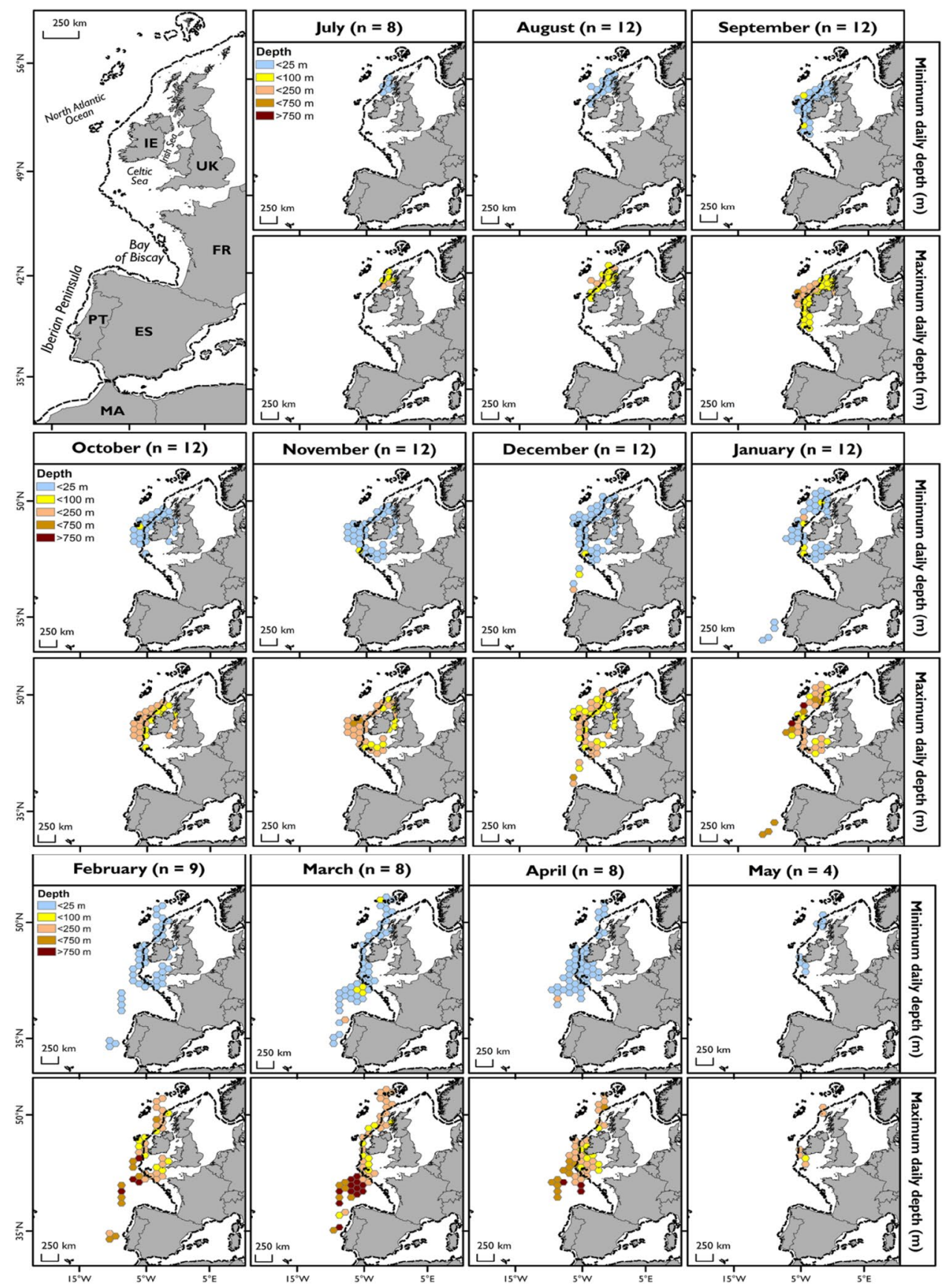

showing evidence of movement into deeper waters (>500 m; Table S2; Fig. 5).

High-resolution time-series data from tags demonstrated basking sharks occupied waters of a mean temperature of $11.6^{\circ} \mathrm{C}\left( \pm 0.24{ }^{\circ} \mathrm{C}\right.$; range $\left.5.5-19.1^{\circ} \mathrm{C}\right)$; however, a mean of $99 \%( \pm 2.8 \% ; 88-100 \%)$ of time was spent in waters of between 8 and $16^{\circ} \mathrm{C}$, with water temperatures experienced by these sharks decreasing with the onset of winter (Fig. 4; Fig. S2). Sea surface temperatures in the same locations that sharks were tracked showed similar seasonal changes and a comparable temperature range to that experienced by basking sharks at depth (mean $11.8{ }^{\circ} \mathrm{C} \pm 1.7$; range $10-14^{\circ} \mathrm{C}$ ).

\section{Discussion}

The need to identify areas providing suitable conditions for large marine vertebrates to undertake key life-history events, such as foraging, mating, and parturition is critical to understanding the biology and ecology of species of conservation concern. Most marine organisms function within 


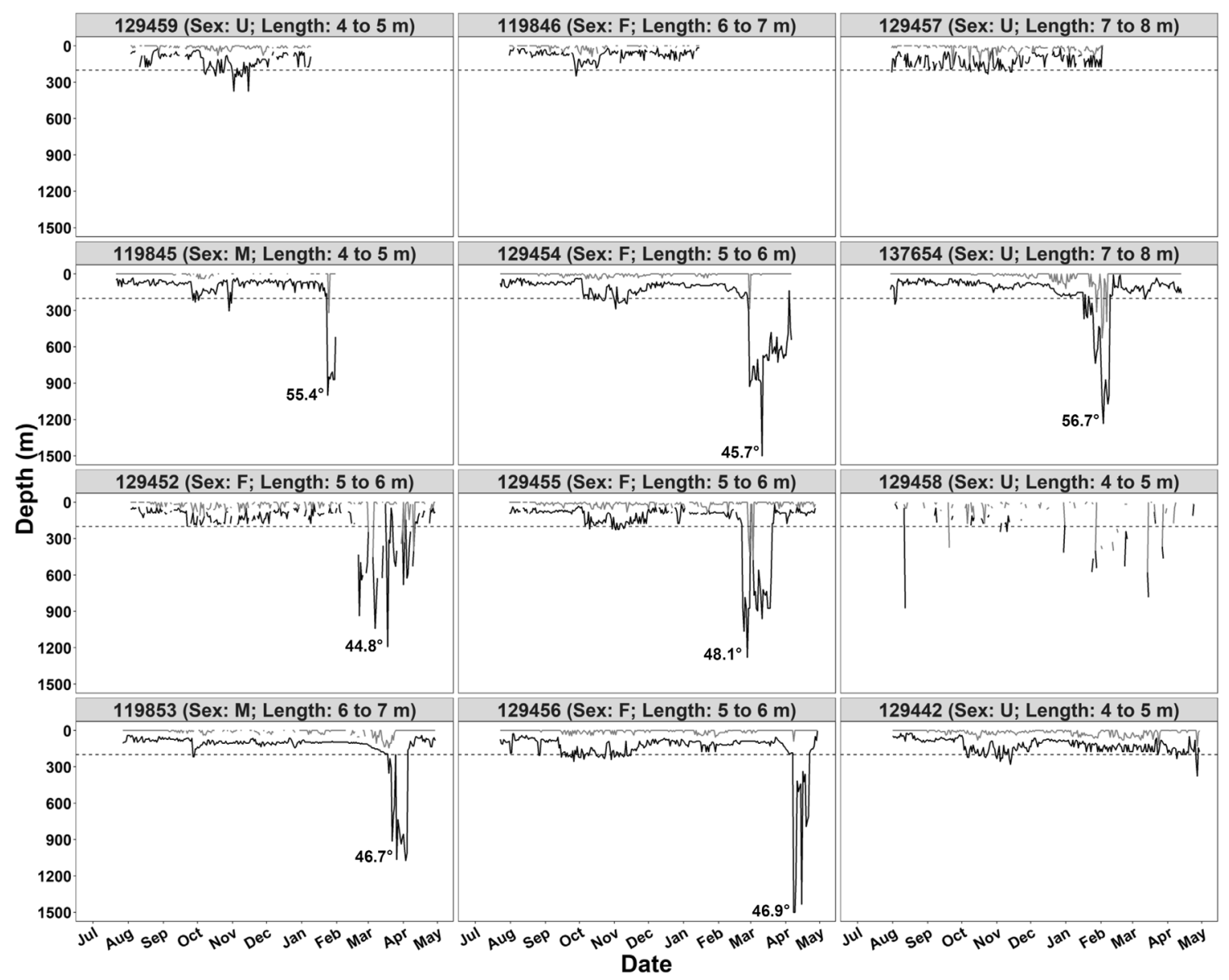

Fig. 3 Basking shark depth-use time-series data. Daily minimum (grey line) and daily maximum (black line) depths from modelled light geolocation positions from archival tags of 12 basking sharks. Latitude of greatest maximum daily depth is shown for sharks exhib-

three-dimensional environments and a number of important factors including; light, pressure, temperature, and oxygen and salinity concentrations vary with depth (Hussey et al. 2015). These physical features of the ocean can act as barriers to species' movement due to adaptations or limitations of physiology and morphology; however, large marine vertebrates can often occupy many distinct vertical habitats (Boustany et al. 2002; Thorrold et al. 2014).

The data demonstrate that basking sharks exhibit seasonal changes in vertical movement in the north-east Atlantic, with shallower vertical space use in summer compared to winter months, whereby sharks occupy epipelagic $(0-200 \mathrm{~m})$ to mesopelagic depths (200-1000 m), with some forays into the bathypelagic zone (1000-4000 m). Basking sharks are capable of finding dense prey patches (Sims et al. 2005, 2006), and activity at the surface during the summer months is likely in relation to these food sources, especially during the day in nearshore waters, with data from the continuous plankton recorder showing increased biomass of copepods iting vertical space use greater than $1000 \mathrm{~m}$. Tag number, sex $(F$ female, $M$ male, and $U$ unknown), and body length (m) shown, dotted line denotes $200 \mathrm{~m}$ depth

in these regions (Richardson et al. 2006). Diel vertical migration (DVM) has been described for all three species of planktivorous sharks: megamouth shark [Megachasma pelagios (Nelson et al. 1997), whale sharks (Rhincodon typus; Graham et al. 2006, Wilson et al. 2006), and basking sharks (Sims et al. 2005; Stéphan et al. 2011)]. Reverse diel vertical migration (rDVM) can also occur, with movements switching towards the surface during the day. Both DVM and rDVM have been observed in whale sharks (Rowat et al. 2006) and basking sharks (Shepard et al. 2006; Stéphan et al. 2011) and may be determined by the heterogeneous environmental conditions of the water column they inhabit. Basking sharks in this study exhibited rDVM during the summer months, moving to relatively shallow waters during daylight hours when they spent the majority of time within the Sea of the Hebrides (Doherty et al. 2017b). During peak winter months, basking sharks switched to exhibiting DVM, likely due to the sharks moving from shallow, well-mixed areas with plankton blooms in summer, which breakdown at 
Fig. 4 Basking shark depth-use from high-resolution time-series data from physically recovered satellite tags. a PAT-F tag depth and temperature recorded at 10-s intervals, b SPLASH-F tag depth and temperature recorded at 15 -s intervals, c PAT-F tag depth and temperature recorded at 10-s intervals, and $\mathbf{d}$, e MiniPAT tag depths and temperatures recorded at 15-s intervals. Left panels: Maps showing movements from archival satellite tags for five basking sharks tracked for over 165 days, displaying modelled light geolocation positions (grey circles) with associated light geolocation error (light grey ellipses), and track end points (white stars). Broken black line denotes $200 \mathrm{~m}$ depth contour. Right panels: Depth (black lines) and temperature (grey lines) time-series data of the same individuals. Blue shaded sections in the left panels correspond to locations highlighted in blue circles in right panel, as regions of deep diving behaviour

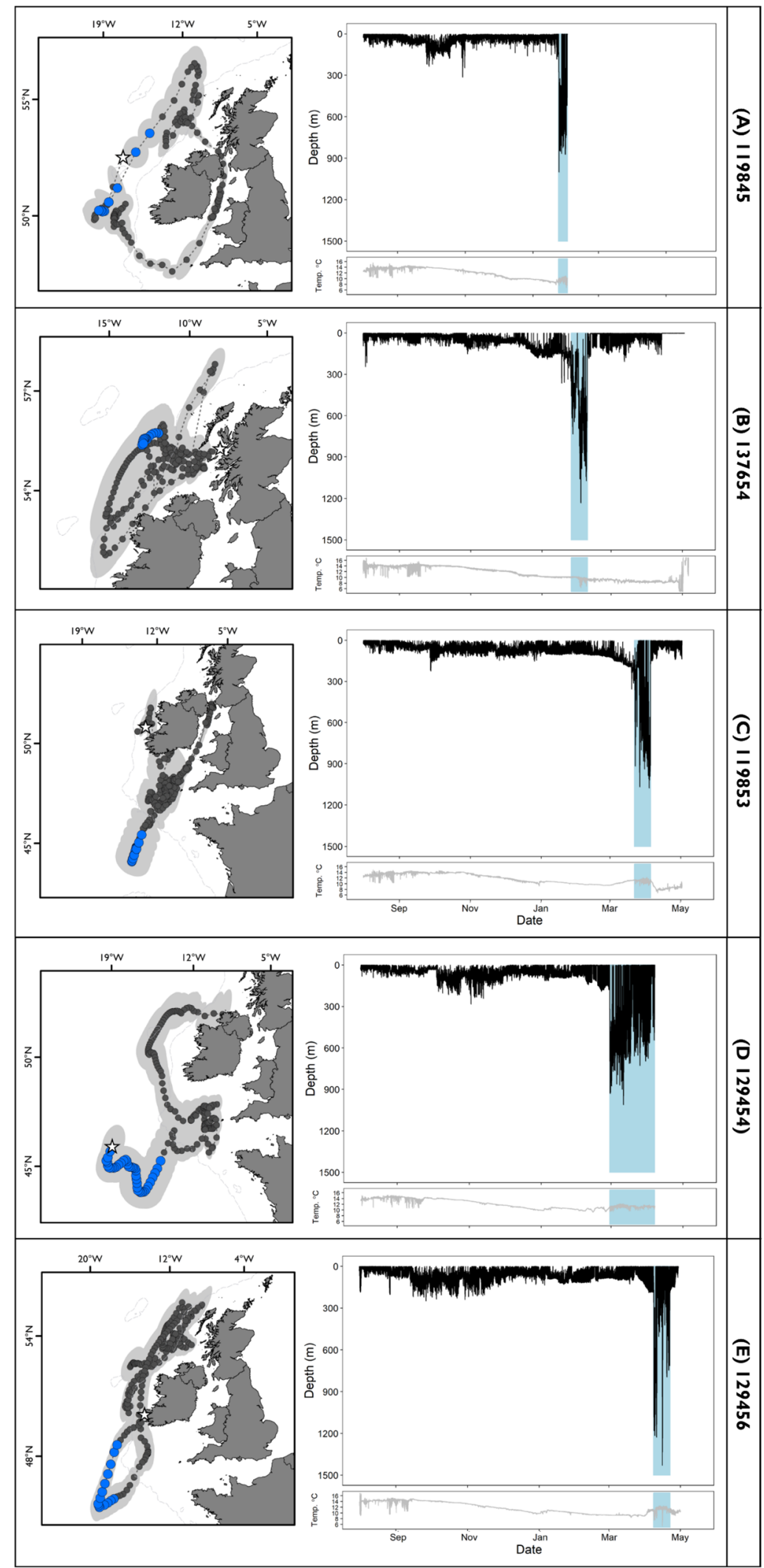


Fig. 5 Spatio-temporal depthuse predictions for basking sharks from a general additive model (GAM). Relationship between latitude and maximum daily depth occupied by basking sharks tracked for extended durations ( $>165$ days; $n=12$ ) for months September to April. Solid black lines denote predictions from general additive model (GAM) with blue polygon representing standard error (se). Month and number of sharks contributing to the plot shown. Rug plots show the latitude at which data are present for each month

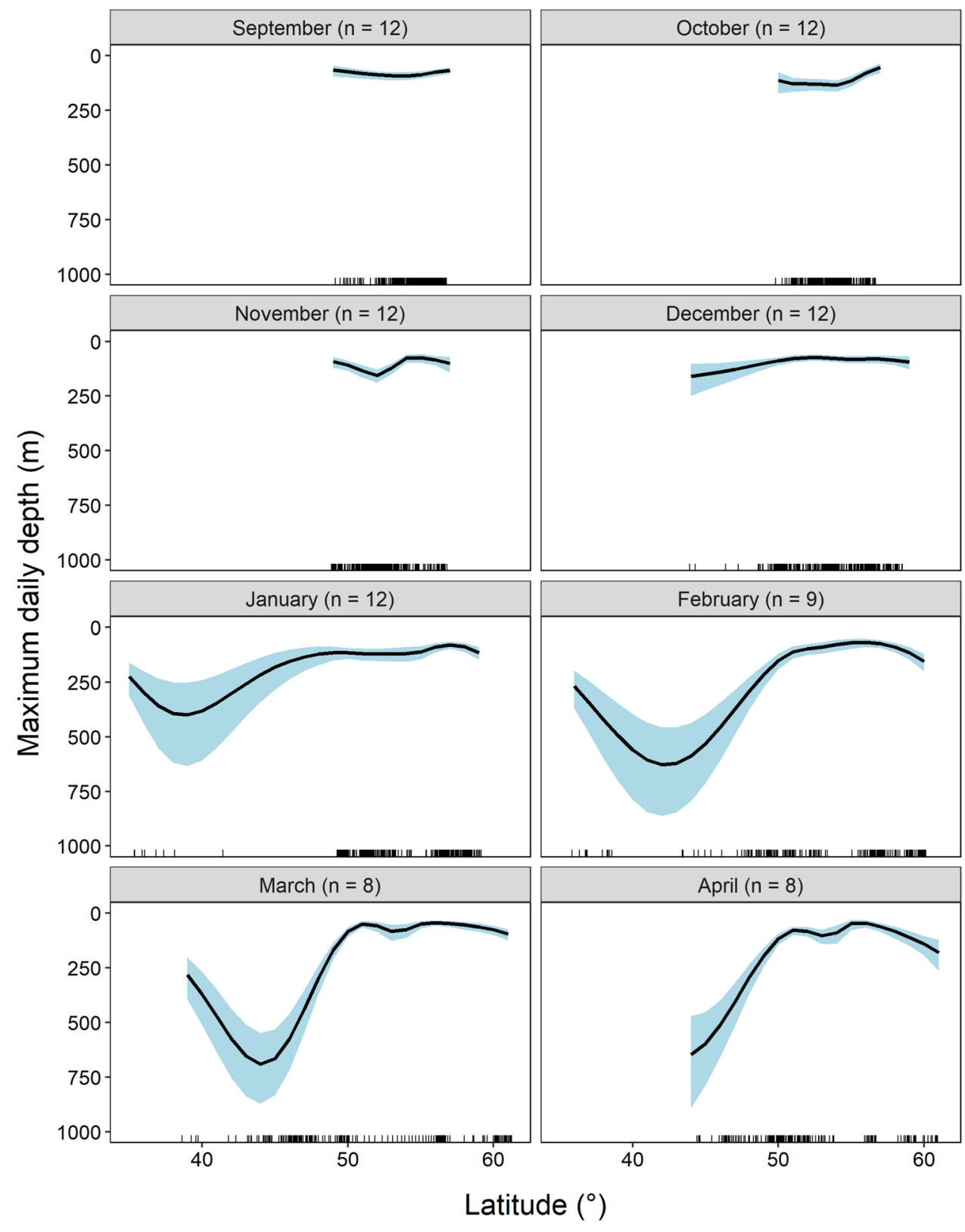

the onset of winter to deeper, more stratified, waters (Sims et al. 2005; Stéphan et al. 2011) sometimes at mesopelagic depths (Gore et al. 2008; Skomal et al. 2009; Doherty et al. 2017a). Copepods dominate zooplankton biomass in the North Atlantic (Gallienne et al. 2001), with basking shark abundance shown to positively correlate with increased abundance of copepods (Sims and Merrett 1997; Sims and Quayle 1998; Sims 1999). The annual life cycle of copepods often includes a period of active feeding and growth in surface waters during spring and summer and a period of diapause in deep water (Hirche 1998). Diapause is characterised by a reduction in development, feeding, and metabolic rates, and is associated with migration to deep water in summer and autumn and ascension towards surface waters in late winter (Hirche 1998). Seasonal cycles also show evidence of predator avoidance by copepods during summer months by reversing migration (rDVM) in relation to predator vertical position during the day (Irigoien et al. 2004). Previous studies have suggested the optimal emergence from diapause in the North Atlantic occurs when copepods overwinter at temperatures less than $5{ }^{\circ} \mathrm{C}$ (Saumweber and Durbin 2006). However, some species undergoing diapause tolerate a broad range of temperatures throughout the North Atlantic ( -1 to $11^{\circ} \mathrm{C}$ ), with dormancy prevailing in higher latitudes (Krumhansl et al. 2018). It is possible that basking sharks have the ability to track the patterns in vertical movement exhibited by prey species by also adopting rDVM movement strategy in summer months when copepods are in surface waters in 
the daytime during the foraging stage of the annual cycle or avoiding predators. During the winter, it is unclear if basking sharks continue to actively feed, but may switch to DVM movements at greater depths to track winter prey daily cycles and/or vertical occupancy during diapause.

Basking sharks in the present study were recorded making repeated 'yo-yo' vertical movement between the surface and deeper waters in late winter-spring (February-April). This has been recorded in a wide range of other shark species including whale sharks (Brunnschweiler et al. 2009), white sharks [Carcharodon carcharias, (Klimley et al. 2002; Domeier and Nasby-Lucas 2008)], scalloped hammerhead sharks (Sphyrna lewini, (Jorgensen et al. 2009)), and tiger sharks (Galeocerdo cuvier (Nakamura et al. 2011)). These behaviours are generally attributed to feeding - when sharks begin to actively seek out foraging areas (horizontally or vertically); however, it is also possible that they are involved in thermoregulation or aid energy conservation (Holland et al. 1992; Klimley et al. 2002; Thums et al. 2013). This type of vertical movement may also serve as a means of orientation, as it has been suggested that sharks use cognitive maps of their home ranges at various spatial scales (Meyer et al. 2010; Papastamatiou et al. 2011).

The spatially explicit data in the present study show evidence of some individuals displaying directed movements off the continental shelf before exhibiting 'yo-yo' vertical behaviour between 6 and 13 days, before returning to continental shelf waters. These movements may be examples of foraging trips, failed foraging trips, or "sampling" of the water column for orientation and/or olfactory cues. Queiroz et al. (2017) showed that basking sharks exhibit "V"shaped time-depth profiles (short durations at maximum depth prior to ascent) to a wide range of depths, further suggesting that these movements serve as an exploratory function. These authors also showed that when approaching an area of increased chlorophyll, maximum depth of V-shaped dives decreased as well as the variation in targeted depths. These repeated movements may represent the beginning of increased activity from a more torpid state during winter months if not actively feeding, or in anticipation of the onset of spring plankton blooms. Olfactory prey cues are considered to be more extensively distributed horizontally than vertically, due to current shear between water layers of different densities (Carey and Scharold 1990; Klimley et al. 2002). Therefore, repeated deep diving behaviour may facilitate sampling of multiple depth layers for chemical cues over short time periods, a behaviour documented for pelagic predatory sharks (Carey and Scharold 1990; Boustany et al. 2002) and is likely a common search strategy for both epipelagic planktivores and macropredators (Sims et al. 2003; Queiroz et al. 2017).

During the present study, we observed several sharks travelling to depths up to $1500 \mathrm{~m}$, most often off the continental shelf to the west of the Bay of Biscay at the Celtic-Armorica shelf margin. This is comparable to the deepest depth recorded for a basking shark of $1504 \mathrm{~m}$ (Braun et al. 2018), with previous observations of basking sharks occupying waters at $1264 \mathrm{~m}$ (Gore et al. 2008), and between 750 and $1000 \mathrm{~m}$ (Francis and Duffy 2002; Sims et al. 2003; Skomal et al. 2009). Other planktivorous elasmobranchs have also been shown to perform vertical space use beyond $1000 \mathrm{~m}$, such as whale sharks diving to $1928 \mathrm{~m}$ (Tyminski et al. 2015) and Chilean devil rays (Mobula tarapacana) diving to $1896 \mathrm{~m}$, suggesting the possibility of foraging at depths providing an important ecological link between surface foragers and forage species occupying pelagic habitats below the euphotic zone (Thorrold et al. 2014).

Basking sharks in this study consistently occupied waters between 8 and $16{ }^{\circ} \mathrm{C}$ regardless of depth or time of year. This appears to be a relatively narrow thermal niche compared to wide ranging teleost fish (Atlantic cod (Gadus morhua) range -1.5 to $20^{\circ} \mathrm{C}$ (Righton et al. 2010); Atlantic bluefin tuna (Thunnus thynnus) range $3-31{ }^{\circ} \mathrm{C}$ (Block et al. 2001)) and sharks (salmon sharks (Lamna ditropis) range $2-24{ }^{\circ} \mathrm{C}$ (Weng 2005); shortfin mako sharks (Isurus oxyrinchus) range $5-30{ }^{\circ} \mathrm{C}$ (Vaudo et al. 2016); white sharks range $5-26^{\circ} \mathrm{C}$ (Boustany et al. 2002); whale sharks range $4-31{ }^{\circ} \mathrm{C}$ (Graham et al. 2006)). This suggests that the vertical space use exhibited by basking sharks in the present study could help to maintain a consistent thermal envelope, which could be advantageous as many physiological rates and functions (e.g. metabolic rate and reproduction) are determined by body temperature (Angilletta et al. 2002; Whitney et al. 2016). We observed basking sharks moving into deeper waters in the winter; however, our results also suggest that conditions may be thermally suitable for basking sharks to occupy surface waters year-round in the north-east Atlantic with sea surface temperature values showing similar seasonal shifts to temperature-at-depth. We observed sharks occupying depths of $1500 \mathrm{~m}$; however, we cannot be certain of the maximum depths these sharks can tolerate, which may be governed by temperature. Other variables such as oxygen levels may impact the depths at which these sharks can occupy (Nasby-Lucas et al. 2009; Prince et al. 2010; Comfort and Weng 2015). Species metabolic rates and, therefore, oxygen requirements may determine environments in which they can inhabit (Bernal et al. 2012). These results may provide evidence for basking sharks feeding on overwintering zooplankton in deeper waters during the winter, although we have no direct observations of this. Incorporating new knowledge of vertical space use into tag programming should be carried out in future research, allowing for depth class assignment to reflect that of what is utilised by sharks. Reducing the breadth of the deeper 
depth classes may allow for further investigation of timings and proportion of time at more extremes of vertical space use for these individuals.

\section{Conclusion}

Characterising vertical space use in basking sharks within areas of high relative importance can contribute to discussions regarding management options for the conservation of basking sharks. Basking sharks exhibit seasonality in their vertical space use, likely reacting to changes in environmental conditions in the areas they inhabit, with occupancy of surprisingly deep waters during the winter. Combining detailed understanding of space use in three dimensions (latitude, longitude, depth, and time) in response to seasonal biological and environmental conditions can elucidate the ecosystem role and environmental preferences of these sharks (Coffey et al. 2017). This spatio-temporally explicit depth information can strengthen our ability to estimate potential interactions with fisheries such as mid-water trawls in order to mitigate bycatch risk. Understanding patterns of habitat use and environmental preferences for species of conservation concern will best inform on implementation of sustainable conservation and management strategies, especially when considering projections of range shifts under future climate scenarios (Hazen et al. 2012b; Miller et al. 2015).

Acknowledgements Tagging in Scotland was funded by Scottish Natural Heritage and the University of Exeter. We extend our sincere thanks to the skippers and crew of the Sula Crion and Bold Ranger of Sea Wild Scotland, Tobermory. PD was funded by an NERC PhD studentship (Grant number: NELIL501669\1).

Funding This study was funded by an NERC PhD studentship (Grant Number: NELIL501669\1).

\section{Compliance with ethical standards}

Conflict of interest The authors declare that they have no conflict of interest.

Ethical approval All applicable international, national, and/or institutional guidelines for the care and use of animals were followed. The attachment of satellite transmitters in Scottish coastal waters was approved by the UK HM Government Home Office under the Animals (Scientific Procedures) Act 1986 (Project Licence 30/2975) and internally through the University of Exeter's Animal Welfare and Ethics Review Board (AWERB). All work was carried out in accordance with the UK HM Government Home Office under the Animals (Scientific Procedures) Act 1986 (Project Licence 30/2975) and under the Wildlife and Countryside Act 1981 (as amended) (Licence(s): 13904, 13937 and 13971).
Open Access This article is distributed under the terms of the Creative Commons Attribution 4.0 International License (http://creativeco mmons.org/licenses/by/4.0/), which permits unrestricted use, distribution, and reproduction in any medium, provided you give appropriate credit to the original author(s) and the source, provide a link to the Creative Commons license, and indicate if changes were made.

\section{References}

Afonso AS, Hazin FHV (2015) Vertical movement patterns and ontogenetic niche expansion in the Tiger Shark, Galeocerdo cuvier. PLoS One 10:e0116720. https://doi.org/10.1371/journ al.pone. 0116720

Agafonkin V, Thieurmel B (2018) suncalc: Compute sun position, sulight phases, moon position and lunar phase. https://CRAN.Rproject.org/package $=$ suncalc. Accessed 01 Aug 2018

Angilletta MJ, Cooper BS, Schuler MS, Boyles JG (2002) The evolution of thermal physiology in endotherms. J Therm Biol 2:249268. https://doi.org/10.2741/E148

Barker MJ, Schluessel V (2005) Managing global shark fisheries: suggestions for prioritizing management strategies. Aquat Conserv Mar Freshw Ecosyst 15:325-347. https://doi.org/10.1002/aqc.660

Barton K (2018) MuMIn: multi-model inference. R Package version 1.42.1: https://CRAN.R-project.org/package $=$ MuMIn. Accessed 01 Aug 2018

Bernal D, Carlson JK, Goldman KJ, Lowe CG (2012) Energetics, metabolism, and endothermy in sharks and rays. Biology of sharks and their relatives, 2nd edn. CRC Press, Boca Raton, pp 211-237

Berrow SD (1994) Incidental capture of elasmobranchs in the bottomset gill-net of the South Coast of Ireland. J Mar Biol Assoc UK 74:837-847

Beyer HL (2012) Geospatial modelling environment (version 0.7.2.1). http://www.spatialecology.com/gme. Accessed 01 Apr 2016

Biais G, Coupeau Y, Seret B, Calmettes B, Lopez R, Hetherington S, Righton D (2017) Return migration patterns of porbeagle shark (Lamna nasus) in the Northeast Atlantic: implications for stock range and structure. ICES J Mar Sci. https://doi.org/10.1093/icesj $\mathrm{ms} / \mathrm{fsw} 233$

Block BA, Dewar H, Blackwell SB, Williams TD, Prince D, Farwell CJ, Boustany A, Teo SLH, Seitz A, Walli A, Fudge D (2001) Migratory movements, depth preferences, and thermal biology of Atlantic Bluefin Tuna. Science 293:1310-1314. https://doi. org/10.1126/science.1061197

Block BA, Jonsen ID, Jorgensen SJ, Winship AJ, Shaffer SA, Bograd SJ, Hazen EL, Foley DG, Breed GA, Harrison A-L, Ganong JE, Swithenbank A, Castleton M, Dewar H, Mate BR, Shillinger GL, Schaefer KM, Benson SR, Weise MJ, Henry RW, Costa DP (2011) Tracking apex marine predator movements in a dynamic ocean. Nature 475:86-90

Bonfil R, Meÿer M, Scholl MC, Johnson R, O’Brien S, Oosthuizen H, Swanson S, Kotze D, Paterson M (2005) Transoceanic migration, spatial dynamics, and population linkages of white sharks. Science 310:100-103

Boustany AM, Davis SF, Pyle P, Anderson SD, Le Boeuf BJ, Block BA (2002) Expanded niche for white sharks. Nature 415:36-37

Braun CD, Skomal GB, Thorrold SR (2018) Integrating archival tag data and a high-resolution oceanographic model to estimate basking shark (Cetorhinus maximus) movements in the Western Atlantic. Front Mar Sci 5:1-14. https://doi.org/10.3389/fmars .2018 .00025

Brunnschweiler JM, Baensch H, Pierce SJ, Sims DW (2009) Deepdiving behaviour of a whale shark Rhincodon typus during longdistance movement in the western Indian Ocean. J Fish Biol 74:706-714. https://doi.org/10.1111/j.1095-8649.2008.02155.x 
Carey FG, Scharold JV (1990) Movements of blue sharks (Prionace glauca) in depth and course. Mar Biol 106:329-342. https://doi. org/10.1007/BF01344309

Coffey DM, Carlisle AB, Hazen EL, Block BA (2017) Oceanographic drivers of the vertical distribution of a highly migratory, endothermic shark. Sci Rep 7:10434. https://doi.org/10.1038/s4159 8-017-11059-6

Comfort CM, Weng KC (2015) Vertical habitat and behaviour of the bluntnose sixgill shark in Hawaii. Deep Sea Res Part II Top Stud Oceanogr 115:116-126. https://doi.org/10.1016/j. dsr2.2014.04.005

Doherty PD, Baxter JM, Gell FR, Godley BJ, Graham RT, Hall G, Hall J, Hawkes LA, Henderson SM, Johnson L, Speedie C, Witt MJ (2017a) Long-term satellite tracking reveals variable seasonal migration strategies of basking sharks in the north-east Atlantic. Sci Rep. https://doi.org/10.1038/srep42837

Doherty PD, Baxter JM, Godley BJ, Graham RT, Hall G, Hall J, Hawkes LA, Henderson SM, Johnson L, Speedie C, Witt MJ (2017b) Testing the boundaries: seasonal residency and interannual site fidelity of basking sharks in a proposed marine protected area. Biol Conserv 209:68-75. https://doi.org/10.1016/j. biocon.2017.01.018

Domeier M, Nasby-Lucas N (2008) Migration patterns of white sharks Carcharodon carcharias tagged at Guadalupe Island, Mexico, and identification of an eastern Pacific shared offshore foraging area. Mar Ecol Prog Ser 370:221-237

Dulvy NK, Simpfendorfer CA, Davidson LNK, Fordham SV, Bräutigam A, Sant G, Welch DJ (2017) Challenges and priorities in shark and ray conservation. Curr Biol 27:R565-R572. https://doi. org/10.1016/j.cub.2017.04.038

Fowler SL (2005) Basking Shark (Cetorhinus maximus). The IUCN red list of threatened species. www.iucnredlist. Accessed 17 Sept 2015

Francis MP, Duffy C (2002) Distribution, seasonal abundance and bycatch of basking sharks (Cetorhinus maximus) in New Zealand, with observations on their winter habitat. Mar Biol 140:831-842

Frid A, Burns J, Baker GG, Thorne RE (2009) Predicting synergistic effects of resources and predators on foraging decisions by Juvenile Steller sea lions. Oecologia 158:775-786. https://doi. org/10.1007/s00442-008-1189-5

Gallienne CP, Robins DB, Woodd-Walker RS (2001) Abundance, distribution and size structure of zooplankton along a $20^{\circ}$ west meridional transect of the northeast Atlantic Ocean in July. Deep Res Part II Top Stud Oceanogr 48:925-949. https://doi. org/10.1016/S0967-0645(00)00114-4

Gore MA, Rowat D, Hall J, Gell FR, Ormond RF (2008) Transatlantic migration and deep mid-ocean diving by basking shark. Biol Lett 4:395-398

Graham RT, Roberts CM, Smart JCR (2006) Diving behaviour of whale sharks in relation to a predictable food pulse. J R Soc Interface 3:109-116. https://doi.org/10.1098/rsif.2005.0082

Hammerschlag N, Gallagher AJ, Lazarre DM (2011) A review of shark satellite tagging studies. J Exp Mar Biol Ecol 398:1-8

Harrison XA, Donaldson L, Correa-Cano ME, Evans J, Fisher DN, Goodwin CED, Robinson BS, Hodgson DJ, Inger R (2018) A brief introduction to mixed effects modelling and multi-model inference in ecology. PeerJ 6:e4794. https://doi.org/10.7717/peerj.4794

Hazen E, Maxwell S, Bailey H, Bograd S, Hamann M, Gaspar P, Godley B, Shillinger G (2012a) Ontogeny in marine tagging and tracking science: technologies and data gaps. Mar Ecol Prog Ser 457:221-240. https://doi.org/10.3354/meps09857

Hazen EL, Jorgensen S, Rykaczewski RR, Bograd SJ, Foley DG, Jonsen ID, Shaffer SA, Dunne JP, Costa DP, Crowder LB, Block BA (2012b) Predicted habitat shifts of Pacific top predators in a changing climate. Nat Clim Chang 3:234-238. https://doi. org/10.1038/nclimate1686
Hetherington S, Townhill B, Borrow K, Bendall V, Hunter E (2015) Shark by-watch UK 2. Research priorities: innovative solutions for reducing by-catch and dead discards of threatened sharks, skates and rays. Shark By-Watch UK (workshop)

Hirche H (1998) Dormancy in three Calanus species (C. finmarchicus, C. glacialis, C. Hyperboreus) from the North Atlantic. Arch Hydrobiol Spec Issue Adv Limnol 52:359-369

Holland KN, Brill RW, Randolph K, Chang RK, Sibert JR, Fournier DA (1992) Physiological and behavioural thermoregulation in bigeye tuna (Thunnus obesus). Nature 358:410-412. https://doi. org/10.1038/358410a0

Hussey NE, Kessel S, Aarestrup K, Cooke SJ, Cowley PD, Fisk AT, Harcourt RG, Holland KN, Iverson SJ, Kocik JF, Mills Flemming JE, Whoriskey FG (2015) Aquatic animal telemetry: a panoramic window into the underwater world. Science 348:1221-1231

Irigoien X, Conway DVP, Harris RP (2004) Flexible diel vertical migration behaviour of zooplankton in the Irish Sea. Mar Ecol Prog Ser 267:85-97. https://doi.org/10.3354/meps267085

Jorgensen SJ, Klimley PA, Muhlia-Melo AF (2009) Scalloped hammerhead shark Sphyrna lewini, utilizes deep-water, hypoxic zone in the Gulf of California. J Fish Biol 74:1682-1687

Klimley PA, Beavers SC, Curtis TH, Jorgensen SJ (2002) Movements and swimming behavior of three species of sharks in La Jolla Canyon, California. Environ Biol Fishes 63:117-135. https://doi. org/10.1023/A:1014200301213

Krumhansl KA, Head EJH, Pepin P, Plourde S, Record NR, Runge JA, Johnson CL (2018) Environmental drivers of vertical distribution in diapausing Calanus copepods in the Northwest Atlantic. Prog Oceanogr 162:202-222. https://doi.org/10.1016/j.pocea n.2018.02.018

Kunzlik PA (1988) The basking shark. Deep Agric Fish Scotland Aberdeen UK 14:1-21

Matich P, Heithaus MR, Layman CA (2011) Contrasting patterns of individual specialization and trophic coupling in two marine apex predators. J Anim Ecol 80:294-305. https://doi.org/10.111 1/j.1365-2656.2010.01753.x

Meyer CG, Papastamatiou YP, Holland KN (2010) A multiple instrument approach to quantifying the movement patterns and habitat use of tiger (Galeocerdo cuvier) and Galapagos sharks (Carcharhinus galapagensis) at French Frigate Shoals, Hawaii. Mar Biol 157:1857-1868

Miller PI, Scales KL, Ingram SN, Southall EJ, Sims DW (2015) Basking sharks and oceanographic fronts: quantifying associations in the north-east Atlantic. Funct Ecol 29:1099-1109. https://doi. org/10.1111/1365-2435.12423

Musyl M, Brill R, Curran D (2011) Postrelease survival, vertical and horizontal movements, and thermal habitats of five species of pelagic sharks in the central Pacific Ocean. Fish Bull 109(4):341-368

Nakamura I, Watanabe YY, Papastamatiou YP, Sato K, Meyer CG (2011) Yo-yo vertical movements suggest a foraging strategy for tiger sharks Galeocerdo cuvier. Mar Ecol Prog Ser 424:237-246. https://doi.org/10.3354/meps08980

Nasby-Lucas N, Dewar H, Lam CH, Goldman KJ, Domeier ML (2009) White shark offshore habitat: a behavioral and environmental characterization of the eastern pacific shared offshore foraging area. PLoS One. https://doi.org/10.1371/journal.pone.0008163

Neilson JD, Loefer J, Prince ED, Royer F, Calmettes B, Gaspar P, Lopez R, Andrushchenko I (2014) Seasonal distributions and migrations of northwest atlantic Swordfish: inferences from integration of Pop-Up satellite archival tagging studies. PLoS One 9:e112736. https://doi.org/10.1371/journal.pone.0112736

Nelson DR, McKibben JN, Strong WR Jr, Lowe CG, Sisneros JA, Schroeder DM, Lavenberg RJ (1997) An acoustic tracking of a megamouth shark, Megachasma pelagios: a crepuscular vertical migrator. Environ Biol Fishes 49:389-399 
Oliver S, Braccini M, Newman SJ, Harvey ES (2015) Global patterns in the bycatch of sharks and rays. Mar Policy 54:86-97. https:// doi.org/10.1016/j.marpol.2014.12.017

Papastamatiou YP, Cartamil DP, Lowe CG, Meyer CG, Wetherbee BM, Holland KN (2011) Scales of orientation, directed walks and movement path structure in sharks. J Anim Ecol 80:864-874. https ://doi.org/10.1111/j.1365-2656.2011.01815.x

Prince ED, Luo J, Phillip Goodyear C, Hoolihan JP, Snodgrass D, Orbesen ES, Serafy JE, Ortiz M, Schirripa MJ (2010) Ocean scale hypoxia-based habitat compression of Atlantic istiophorid billfishes. Fish Oceanogr 19:448-462. https://doi.org/10.111 $1 / \mathrm{j} .1365-2419.2010 .00556 . x$

Queiroz N, Vila-Pouca C, Couto A, Southall EJ, Mucientes G, Humphries NE, Sims DW (2017) Convergent foraging tactics of marine predators with different feeding strategies across heterogeneous ocean environments. Front Mar Sci 4:1-15. https://doi. org/10.3389/fmars.2017.00239

R Core Team (2018) R: a language and environment for statistical computing. R Foundation for Statistical Computing, Vienna

Richardson AJ, Walne AW, John AWG, Jonas TD, Lindley JA, Sims DW, Stevens D, Witt M (2006) Using continuous plankton recorder data. Prog Oceanogr 68:27-74. https://doi.org/10.1016/j. pocean.2005.09.011

Righton DA, Andersen KH, Neat F, Thorsteinsson V, Steingrund P, Svedäng H, Michalsen K, Hinrichsen HH, Bendall V, Neuenfeldt S, Wright P, Jonsson P, Huse G, Van Der Kooij J, Mosegaard H, Hüssy K, Metcalfe J (2010) Thermal niche of Atlantic cod Gadus morhua: limits, tolerance and optima. Mar Ecol Prog Ser 420:1-13. https://doi.org/10.3354/meps08889

Roberts JJ, Best BD, Dunn DC, Treml EA, Halpin PN (2010) Marine geospatial ecology tools: an integrated framework for ecological geoprocessing with ArcGIS, Python, R, MATLAB, and C++. Environ Model Softw 25:1197-1207. https://doi.org/10.1016/j. envsoft.2010.03.029

Rowat D, Meekan MG, Engelhardt U, Pardigon B, Vely M (2006) Aggregations of juvenile whale sharks (Rhincodon typus) in the Gulf of Tadjoura, Djibouti. Environ Biol Fishes 80:465-472. https ://doi.org/10.1007/s10641-006-9148-7

Saumweber WJ, Durbin EG (2006) Estimating potential diapause duration in Calanus finmarchicus. Deep Res Part II Top Stud Oceanogr 53:2597-2617. https://doi.org/10.1016/j.dsr2.2006.08.003

Schmitz OJ, Hawlena D, Trussell GC (2010) Predator control of ecosystem nutrient dynamics. Ecol Lett 13:1199-1209. https://doi. org/10.1111/j.1461-0248.2010.01511.x

Schorr GS, Falcone EA, Moretti DJ, Andrews RD (2014) First longterm behavioral records from Cuvier's beaked whales (Ziphius cavirostris) reveal record-breaking dives. PLoS One 9:e92633. https://doi.org/10.1371/journal.pone.0092633

Shepard ELC, Ahmed MZ, Southall EJ, Witt MJ, Metcalfe JD, Sims DW (2006) Diel and tidal rhythms in diving behaviour of pelagic sharks identified by signal processing of archival tagging data. Mar Ecol Prog Ser 328:205-213. https://doi.org/10.3354/meps3 28205

Sims DW (1999) Threshold foraging behaviour of basking sharks on zooplankton: life on an energetic knife-edge? Proc R Soc B 266:1437-1443

Sims DW, Merrett DA (1997) Determination of zooplankton characteristics in the presence of surface feeding basking sharks Cetorhinus maximus. Mar Ecol Prog Ser 158:297-302

Sims DW, Quayle VA (1998) Selective foraging behaviour of basking sharks on zooplankton in a small-scale front. Nature 393:460-464

Sims DW, Southall EJ, Richardson AJ, Reid PC, Metcalfe JD (2003) Seasonal movements and behaviour of basking sharks from archival tagging: no evidence of winter hibernation. Mar Ecol Prog Ser 248:187-196

Sims DW, Southall EJ, Tarling GA, Metcalfe JD (2005) Habitat-specific normal and reverse diel vertical migration in the planktonfeeding basking shark. J Anim Ecol 74:755-761

Sims DW, Witt MJ, Richardson AJ, Southall EJ, Metcalfe JD (2006) Encounter success of free-ranging marine predator movements across a dynamic prey landscape. Proc R Soc B 273:1195-1201

Skomal GB, Zeeman SI, Chisholm JH, Summers EL, Walsh HJ, McMahon KW, Thorrold SR (2009) Transequatorial migrations by basking sharks in the western Atlantic Ocean. Curr Biol 19:1019-1022

Stéphan E, Gadenne H, Jung A (2011) Satellite tracking of basking sharks in the North-East Atlantic Ocean. Association Pour l'Etude et La Conservation Des Sélaciens (Non-Governmental Organization for the Study and Conservation of Elasmobranchs). Final report

Thorrold SR, Afonso P, Fontes J, Braun CD, Santos RS, Skomal GB, Berumen ML (2014) Extreme diving behaviour in devil rays links surface waters and the deep ocean. Nat Commun 5:4274. https:// doi.org/10.1038/ncomms5274

Thums M, Meekan M, Stevens J, Wilson S, Polovina J (2013) Evidence for behavioural thermoregulation by the world's largest fish. J R Soc Interface 10:2-6. https://doi.org/10.1098/rsif.2012.0477

Thygesen UH, Pedersen MW, Madsen H (2009) Geolocating fish using hidden Markov models and data storage tags. In: Nielsen JL, Arrizabalaga H, Fragoso N, Hobday A, Lutcavage M, Sibert $\mathbf{J}$ (eds) Tagging and tracking of marine animals with electronic devices. Springer, Netherlands, pp 277-293

Tyminski JP, de la Parra-Venegas R, González Cano J, Hueter RE (2015) Vertical movements and patterns in diving behavior of whale sharks as revealed by pop-up satellite tags in the eastern Gulf of Mexico. PLoS One 10:e0142156. https://doi.org/10.1371/ journal.pone. 0142156

Vaudo JJ, Wetherbee BM, Harvey G, Nemeth RS, Aming C, Burnie N, Howey-Jordan LA, Shivji MS (2014) Intraspecific variation in vertical habitat use by tiger sharks (Galeocerdo cuvier) in the western North Atlantic. Ecol Evol 4:1768-1786. https://doi. org/10.1002/ece3.1053

Vaudo J, Wetherbee B, Wood A, Weng K, Howey-Jordan L, Harvey G, Shivji M (2016) Vertical movements of shortfin mako sharks Isurus oxyrinchus in the western North Atlantic Ocean are strongly influenced by temperature. Mar Ecol Prog Ser 547:163-175. https ://doi.org/10.3354/meps 11646

Weng KC (2005) Satellite tagging and cardiac physiology reveal niche expansion in salmon sharks. Science 310:104-106. https://doi. org/10.1126/science.1114616

Whitney NM, Lear KO, Gaskins LC, Gleiss AC (2016) The effects of temperature and swimming speed on the metabolic rate of the nurse shark (Ginglymostoma cirratum, Bonaterre). J Exp Mar Biol Ecol 477:40-46. https://doi.org/10.1016/j.jembe.2015.12.009

Wilson SG, Polovina JJ, Stewart BS, Meekan MG (2006) Movements of whale sharks (Rhincodon typus) tagged at Ningaloo Reef, Western Australia. Mar Biol 148:1157-1166. https://doi.org/10.1007/ s00227-005-0153-8

Wood S (2017) Generalized additive models: an introduction with R, 2nd edn. Chapman \& Hall/CRC, Boca Raton

Publisher's Note Springer Nature remains neutral with regard to jurisdictional claims in published maps and institutional affiliations. 